\title{
Magnitude of undiagnosed diabetes mellitus and associated factors among middle aged urban residents in west Ethiopia.
}

\author{
Alemu A Feyissa ( $\sim$ alemuadeba2017@gmail.com ) \\ Jimma University https://orcid.org/0000-0002-4384-9827 \\ Dessalegn Tamiru \\ Jimma University \\ Tefera Belachew \\ Jimma University
}

\section{Research Article}

Keywords: Undiagnosed diabetes, risks, Middle aged, West Ethiopia

Posted Date: June 21st, 2021

DOI: https://doi.org/10.21203/rs.3.rs-624255/v1

License: (c) (i) This work is licensed under a Creative Commons Attribution 4.0 International License. Read Full License 


\section{Abstract \\ Background}

People die due to biologically impairment than chronological aging worldwide. Diabetic mellitus is becoming public health problem and undiagnosed diabetes is a challenge for health providers. Nevertheless, the prevalence and associated factors of undiagnosed diabetes in west Ethiopian unnoticed at community level.

\section{Objective}

To Investigate the magnitude of undiagnosed diabetes(T2DM) and associated factors among middle aged urban residents in west Ethiopia.

\section{Methods}

A community based cross-sectional study was conducted in March 01-30, 2019 on 266 undiagnosed middle aged urban residents. Data were collected using questionnaires, anthropometric measures and biomarkers. Fasting blood glucose $\geq 126 \mathrm{mg} / \mathrm{dl}$ at morning were taken as diabetes. With SPSS version 24 multivariable logistic regression analyses was applied and associated factors at $95 \% \mathrm{Cl}$ with $\mathrm{p} \leq 0.05$ considered statistically significant.

\section{Results}

The overall prevalence of undiagnosed diabetic mellitus was 7.14\% among urban residents in west Ethiopia. Being having sleep apnea, sedentary life, high (waist circumference, waist to height ratio, BMI, triglycerides, and blood pressure) were significantly associated with elevated fasting blood glucose. On multivariable logistic regression analysis: being high BMI four times (AOR: 4.87; $p=0.049$ ), elevated blood pressure five times (AOR: 5.22; $p=0.005)$, and sleep apnea $(p=0.023)$ were associated significantly.

\section{Conclusion}

This study revealed undiagnosed diabetes was prevalent and associated to its risk factors in west Ethiopia. Therefore, community based education and early detection were significant to reduce the burden of diabetic mellitus.

\section{Introduction}

Diabetes Mellitus (DM) is one of the four major NCDs causing a high morbidity and mortality globally. DM is a metabolic disorder of multiple etiologies characterized by chronic hyperglycemia induced from defects of insulin secretion and action or both [IDF, 2013].

In long acting elevated blood glucose leads to micro and macro vascular complications [Chawla A, et al, 2016] and it becomes serious health problem unless early screened [WHO,2014]. Complication from undiagnosed diabetes leads to significant decline in quality of life [Hajifathalian K, et al, 2016] and the risk for premature death [WHO, 2016] which is prevented through early diagnosis of risks. 
Globally, the magnitude of diabetes has been increasing among adults; 451 million people living with diabetes as of International diabetes Federation Atlas report in 2017, and projected to tall to 693 million by 2045[Karuranga S, et al, 2017]. Residentially base the prevalence of diabetes higher in urban than rural area [Huang Y, et al, 2017].

In 2014, about 179.2 million people lived with undiagnosed DM worldwide and African region had the highest percentage compared with others. About $62.3 \%$ of the people with the diseases do not know their being affected, and about 13.4 million had undiagnosed DM [Henriksen O, et al.2011; Motala A, \& Ramaiya K, 2010; Roglic G., 2016].

In Ethiopia, the magnitude of diabetes is increasing; according to the WHO report, the number of cases was 800000 in 2000 , and is rising to an estimated 1.8 million by 2030[Shimels T, et al.2016, Yemane T, et al.2007]. Evidence from studies conducted in Ethiopia: in Gondar and Bahir dar city were 2.3\% and 10.2\% individuals lived with undiagnosed DM respectively [Gelaw YA, et al.2017; Bantie GM, et al. 2019]. Like to other world, study conducted in 2014 in Ethiopia showed, about 1,603,100(75.1\%) of populations undiagnosed for diabetes mellitus [IDF, 2013, Beagley J,et al, 2014].

However, different factors contributed to risk of diabetes developing; it is not understood by community. Although undiagnosed DM prevalent; it was not addressed well Ethiopia, nothing has been done in community setting. Therefore, this study aimed to assess the magnitude of undiagnosed type two diabetic and its associated factors among middle aged urban residents in west Ethiopia.

\section{Methods}

\section{Study design, setting and period}

A community- based cross- sectional study was conducted in hub of west Ethiopia Town in March 1-30, 2019. The Nekemte is located $328 \mathrm{~km}$ from Addis Ababa. Administratively, it is divided in to six sub cities. Its altitude ranges from 1960 to 2170 Meters above sea level where as its average annual rain fall is $1854.9 \mathrm{~mm}$ and the average temperature ranges from $14^{\circ \mathrm{C}}$ to $26^{\circ \mathrm{C}}$. The total population of the city projection in 2017 is estimated to be 117,819 and of this $51 \%(60,088)$ of them were adults.

\section{Sample size and techniques}

Since there was no prior study at the study site regarding metabolic syndrome, the minimum sample size was calculated using single proportion formula taking prevalence of dependent variable among healthy Ethiopian adults. According to [Girma B, et al. 2011], the most common component of metabolic syndrome is abdominal obesity with $19.6 \%$ prevalent. So, with margin of error of $5 \%$, a confidence level of $95 \%$ and $10 \%$ gnawing away, minimum sample of 266 participants.

Adults aged 41-64 years who were eligible to participate in the study and asked to undergo diagnosis and respond questionnaires. While diagnosed and who have been receiving medication for NCDs, pregnant, lactating, serious mental conditions, bariatric surgery and physically disables will be excluded. To reduce bias, one commune was selected by simple random sampling (Chalalaki), and control one (Burkajato) purposively selected from six sub-cities.

\section{Measurements}

Data were collected using structured self administered questionnaire, and anthropometric measurements were taken from each participant. Fasting blood sugar (FBS) level was determined by samples taken early in the morning and readings of $\mathrm{FBS} \geq 126 \mathrm{mg} / \mathrm{dL}$ were classified as diabetes. Also other biomarkers were collected to assess common associated risk factors of DM. 


\section{Analysis}

The data analyzed using SPSS version 24(IBM corporation, NY, USA). Frequency, percentage and descriptive summaries used to explain the amount of study participants in the analysis. Descriptive statistics were used to summaries and describe various sample characteristics and association between high blood glucose and risk factors. The binary regression computed the crude OR and variables with $p$ values less than 0.2 were entered into multivariable logistic regression model to control potential confounding effects in the model. The strength of associations between independent and outcome variables was assessed using AOR with a 95\% Cl; $\mathrm{p}$ values $\leq 0.05$ were considered as statistically significant predictors of undiagnosed DM.

\section{Ethical review and confidentiality}

Permission was sought from the Institutional Review Board (IRB), Institute of Health, Jimma University (1 January, Approval No. IHRPGD/596/2019) to conduct the study. The households, which affirmed their willingness to participate in the study, signed a consent form. Confidentiality of the respondents was ensured and each household had its own identification number. Subjects were free to participate in the study without any fear of retribution.

\section{Results}

\section{Socio-demographic and lifestyles characteristics}

Of hundred sixty six undiagnosed participants with age of 41-64 years range were comprised, majority (62.8\%) of them were females. The average age of adults in our sample was 52.2 years, participants aged $41-48$ years accounted for $54.5 \%$; more than half $(54.89 \%)$ of the participants were live below poverty threshold ( $<1.25$ dollar/day). Regarding to the lifestyle behaviors, majority (75.2\%) of them live sedentary life, about $40.6 \%$ sleep fragmented types, $24.8 \%$ had history of alcohol intake, currently $1.1 \%$ chewing khat and $2.3 \%$ smoking cigarette, the most common selfreported substance use. Besides these almost majority (91\%) of the participants performed low physical activity as compared to standard (Table 1). 
Table 1

Socio-demographic and lifestyle behavioral characteristics of participants in urban residents of west Ethiopia ,2019 ( $n=266)$

\begin{tabular}{|c|c|c|c|}
\hline & & \multicolumn{2}{|l|}{ Undiagnosed DM } \\
\hline & & Present (\%), n= 19 & Absent (\%),n = 247 \\
\hline \multirow[t]{2}{*}{ Sex } & Female & $12(4.51)$ & 155(58.27) \\
\hline & Male & $7(2.63)$ & $92(34.59)$ \\
\hline \multirow[t]{3}{*}{ Age in years } & Range from $41-48$ years & $10(3.7)$ & $135(50.75)$ \\
\hline & Range from $49-56$ years & $5(1.8)$ & 72(27.07) \\
\hline & Range from 57-64years & $4(1.5)$ & $140(52.63)$ \\
\hline \multirow[t]{4}{*}{ Educational status } & Illiterate & $5(1.89)$ & $81(30.45)$ \\
\hline & Some school & $10(3.78)$ & 109(40.98) \\
\hline & Diploma & $3(1.13)$ & $30(11.28)$ \\
\hline & Degree and above & $1(0.38)$ & $27(10.15)$ \\
\hline \multirow[t]{4}{*}{ Marital status } & Unmarried & $1(0.38)$ & $12(4.51)$ \\
\hline & Married & $15(5.64)$ & 163(61.28) \\
\hline & Widowed & $2(0.75)$ & $54(20.30)$ \\
\hline & Divorced & $1(0.38)$ & $18(6.77)$ \\
\hline \multirow[t]{2}{*}{ Daily income } & $\geq 1.25$ USD & $10(3.78)$ & $110(41.35)$ \\
\hline & $<1.25 U D$ & $9(3.38)$ & $137(51.50)$ \\
\hline \multirow[t]{3}{*}{ Physical activity } & Low & $18(6.77)$ & $224(84.21)$ \\
\hline & Moderate $>120<150 \mathrm{M}^{\prime} / \mathrm{W}$ & 0 & $13(4.89)$ \\
\hline & Vigorous $>150 \mathrm{M}^{\prime} / \mathrm{W} / 3$ days & $1(0.38)$ & 10(3.78) \\
\hline \multirow[t]{3}{*}{ Smoking } & Current & 0 & $6(2.26)$ \\
\hline & Former & $2(0.75)$ & $19(7.14)$ \\
\hline & Never & 17(6.39) & 222(83.46) \\
\hline \multirow[t]{3}{*}{ Alcohol consumption } & Current & $3(1.13)$ & $23(8.65)$ \\
\hline & Former & $4(1.5)$ & $36(13.53)$ \\
\hline & Never & $12(4.51)$ & 188(70.68) \\
\hline \multirow[t]{3}{*}{ Chewing of chat } & Current & 0 & $3(1.13)$ \\
\hline & Former & $2(0.75)$ & $16(6.02)$ \\
\hline & Never & 17(6.39) & $228(85.71)$ \\
\hline \multirow[t]{2}{*}{ Healthy diet } & Low DD score & 13(4.89) & 168(63.16) \\
\hline & Medium DD score & $6(2.26)$ & $70(26.32)$ \\
\hline
\end{tabular}




\begin{tabular}{|cll|}
\hline & \multicolumn{2}{l|}{ Undiagnosed DM } \\
\cline { 2 - 3 } & Present (\%), $\mathbf{n = 1 9}$ & Absent (\%), $\mathbf{n = 2 4 7}$ \\
\hline High DD score & 0 & $9(3.38)$ \\
\hline DM: diabetic mellitus, DD: dietary diversity, USD: US dollar, & \\
\hline
\end{tabular}

\section{Factors associated with undiagnosed diabetes}

The prevalence of diabetes was averagely $7.14 \%$ and significantly associated with sleep, sedentary life, WC, waist to height ratio, $\mathrm{BMI}$, blood pressure, TG and $\mathrm{HDL}$ on binary analysis. The multivariate logistic regression analysis showed that only sleep, BMI and blood pressure were independently associated with diabetes.

The mean fasting blood glucose level was 99.67 (29.60) mg/dl with (95\%CL: 96.12, 103.27; $\mathrm{p}<0.0001)$. The prevalence of undiagnosed DM was found to be $6.4 \%$ with a fasting blood glucose level $\geq 126 \mathrm{mg} / \mathrm{dL}$ and $15.8 \%$ individuals were live with impaired fasting glucose. The prevalence of diabetes significantly increased with high BMl; diabetes prevalence in participants with high $\mathrm{BMI}(6.02 \%)$ is significantly higher than that in participants with BMI less than $25 \mathrm{Kg} / \mathrm{m}^{2}(1.13 \%)$ by factor of AOR: $(4.87(1.01,23.45), P=0.048)$. More than half $(69.26 \%)$ of the study participants have central obesity (high waist circumference), and the prevalence of diabetes is higher in participants with high waist circumference $(6.39 \%$ ) compared to $0.75 \%$ of the participants with normal/low waist circumference $(A O R=1.61(1.14,18.53), P=0.702)$, but not significantly associated (Table 2$)$.

In addition, our study revealed those participants who had sleep apnea had $3.47(\mathrm{OR}=41.37 \mathrm{Cl}=(1.02,11.81, \mathrm{p}=$ $0.046)$ times higher chance of having diabetes than normal range of sleeping hours. Being having sleep apnea AOR: $(0.19(0.05,0.80), P=0.023)$ and elevated blood pressure greater than $130 / 85 \mathrm{mmHg}$ AOR: $(5.22(1.67,16.33), P=$ 0.005 ) were significantly associated with undiagnosed DM (Table 2). 
Table 2

Multivariable logistic regression analysis to identify factors associated with undiagnosed diabetes among urban residents of west Ethiopia, $2019(n=266)$

\begin{tabular}{|c|c|c|c|c|c|c|c|}
\hline \multirow[t]{2}{*}{ Variable } & \multirow[t]{2}{*}{ Categories } & \multicolumn{2}{|c|}{ Undiagnosed DM (\%) } & \multirow[t]{2}{*}{$\operatorname{COR}(95 \% \mathrm{Cl})$} & \multirow{2}{*}{$\begin{array}{l}P- \\
\text { value }\end{array}$} & \multirow[t]{2}{*}{ AOR $(95 \% \mathrm{Cl})$} & \multirow{2}{*}{$\begin{array}{l}\mathrm{P}- \\
\text { value }\end{array}$} \\
\hline & & Present & Absent & & & & \\
\hline \multirow{3}{*}{$\begin{array}{l}\text { History of } \\
\text { sleep }\end{array}$} & Has apnea & $4(1.5)$ & 88(33.08) & $3.47(1.02,11.81)$ & 0.046 & $0.19(0.05,0.80)$ & 0.023 \\
\hline & Deprived < 6hrs & $6(2.26)$ & 102(38.34) & $2.68(1.91,7.93)$ & 0.074 & $0.35(0.10,1.18)$ & 0.089 \\
\hline & Normal(6-8hrs) & $9(3.38)$ & $57(21.43)$ & 1 & & 1 & \\
\hline \multirow{2}{*}{$\begin{array}{l}\text { Sedentary } \\
\text { life }\end{array}$} & yes & $12(4.51)$ & 188(70.68) & $1.84(1.70,4.94)$ & 0.200 & $0.80(0.25,2.50)$ & 0.697 \\
\hline & No & $7(2.63)$ & $59(21.18)$ & 1 & & 1 & \\
\hline \multirow{2}{*}{$\begin{array}{l}\text { WC } \\
\text { (Male/ } \\
\text { Female) }\end{array}$} & $\geq 94 \mathrm{~cm} / 80 \mathrm{~cm}$ & $17(6.39)$ & $139(52.26)$ & $0.15(0.04,0.67)$ & 0.013 & $1.61(1.14,18.53)$ & 0.702 \\
\hline & $<94 \mathrm{~cm} / 80 \mathrm{~cm}$ & $2(0.75)$ & 108(40.60) & 1 & & 1 & \\
\hline \multirow[t]{2}{*}{$\begin{array}{l}\text { Waist to } \\
\text { ht ratio }\end{array}$} & $\begin{array}{l}> \\
0.49 / 0.50(\mathrm{M} / \mathrm{F})\end{array}$ & 17(6.39) & 148(55.64) & $5.69(1.29,25.16)$ & 0.022 & $1.99(1.19,20.88)$ & 0.565 \\
\hline & $\begin{array}{l}< \\
0.49 / 0.50(\mathrm{M} / \mathrm{F})\end{array}$ & $2(0.75)$ & $99(37.22 \%)$ & 1 & & 1 & \\
\hline \multirow[t]{2}{*}{$\mathrm{BMI}$} & $\geq 25 \mathrm{~kg} / \mathrm{m} 2$ & $16(6.02)$ & 103(38.72) & $0.14(0.04,0.47)$ & 0.002 & $4.87(1.01,23.45)$ & 0.049 \\
\hline & $<25 \mathrm{~kg} / \mathrm{m} 2$ & $3(1.13)$ & 144(54.14) & 1 & & 1 & \\
\hline \multirow{2}{*}{$\begin{array}{l}\text { Elevated } \\
\text { BP }\end{array}$} & $\underset{135 / 85 \mathrm{mmHg}}{\geq}$ & 10(3.78) & $39(14.66)$ & $0.17(0.07,0.44)$ & 0.000 & $5.22(1.67,16.33)$ & 0.005 \\
\hline & $<$ & $9(3.38)$ & 208(78.20) & 1 & & 1 & \\
\hline \multirow{2}{*}{$\begin{array}{l}\text { Raised } \\
\text { TGs }\end{array}$} & $\geq 150 \mathrm{mg} / \mathrm{dl}$ & $10(3.78)$ & $44(16.54)$ & $5.13(1.97,13.36)$ & 0.001 & $1.27(0.34,4.80)$ & 0.722 \\
\hline & $<150 \mathrm{mg} / \mathrm{dl}$ & $9(3.38)$ & 203(76.32) & 1 & & 1 & \\
\hline \multirow[t]{2}{*}{$\begin{array}{l}\text { HDL low } \\
\text { in (mg/dl) }\end{array}$} & $\begin{array}{l}<40,50 \text { for } \\
M / F\end{array}$ & $8(3.01)$ & $43(16.17)$ & $3.45(1.31,9.09)$ & 0.012 & $0.38(0.11,1.31)$ & 0.123 \\
\hline & $\begin{array}{l}>40,50 \text { for } \\
M / F\end{array}$ & $11(4.14)$ & 204(76.79) & 1 & & 1 & \\
\hline
\end{tabular}

\section{Discussion}

The current prevalence of T-2DM was 7.14\% and slightly higher than the study some urban residents like in Gonder city (5.1\%)[ Atlas D, 2015]; and estimated Ethiopian prevalence of DM (5.2\%) by IDFA [Atlas D, 2015]; Dessie Town, Northeast Ethiopia (6.8\%) [Endris et al, 2019]; Mizan-Aman Town, south Ethiopia (6.5\%) [Aynalem SB and Zeleke AJ,2016].

In contrary, a study conducted on HIV/AIDS patients taking HAART in Ethiopia showed DM prevalence of as high as 8\% has been reported in 2013 [Internat STD Rese \&Revi2013, in Jimma reported 15\% Impaired Glucose Tolerances [Yemane T. et al, 2007]. Likewise, the prevalence of DM was lower than studies done in North India, Punjab (8.3\%) 
[Jeet G, et al, 2017], Pakistan (26.3\%)[ Basit A, et al, 2018 ] and in Bangladeshi (9.7\%)[ Akter S, 2014]. This difference might be due to variation in socio-demographic and lifestyle behavior factors.

As estimated, diabetes is associated with increasing adults aged $\geq 40$ years, similarly the magnitude of undiagnosed diabetes significantly high in study participants with age 41-64 years. This is in agreement to previous studies in African countries [Maugendre D. et al, 2007; Mbanya et al, 1999]; including Ethiopia [Abebe et al,2014; Nigatu T. 2012].

Diabetic patients often have a high prevalence of obstructive sleep apnea (OSA) [Berne C, et al. 2001]. Clinical studies have shown an increase in serum glucose in patients with OSA independent of obesity [Lam KS et al.2002, Punjabi $\mathrm{NM}$ et al.2002]. In the present study we observed an independently association between high glucose levels and sleep apnea. The association of sleep disorder and diabetes was found to be statistically significant $(P=0.023)$.

\section{Conclusions}

In this study we found that the prevalence of undiagnosed diabetic mellitus was $7.14 \%$ and it was significantly associated with sleep apnea, high BMI and elevated blood pressure. Therefore, to reduce the magnitude, it is recommended: active screening for early detection of diabetes and face-t0-face education would bring significant changes.

\section{Limitations of the Study}

The study is subject to recall bias because of the cross sectional nature and limitation to take large study population.

\section{Declarations}

\section{Consent for Publication}

- Not applicable

\section{Competing Interests}

- We declare that we have no competing interests.

\section{Funding and Author Contributions}

The authors received no financial support for the publication of the article. All authors made substantial contributions to conception design of the study, data collection, analysis, interpretation and manuscript writing to final approval of the version to be published.

\section{Acknowledgements}

We acknowledge all participants, professionals, Wollega University specialized hospital, cheleleki clinic and administrative of Nekemte municipal for their great cooperation for the success of the study.

\section{References}

1. IDF. IDF diabetes atlas. International diabetes Federation; 2013.

2. Ip MS, Lam B, Ng MM, Lam WK, Tsang KW, Lam KS. Obstructive sleep apnea is independently associated with insulin resistance. Am J Respir Crit Care Med 2002; 165 (5): 670-6. 
3. Punjabi NM, Sorkin JD, Katzel LI, Goldberg AP, Schwartz AR, Smith PL. Sleep disorder breathing and insuline resistance in middle-aged and overweight men. Am J Respir Crit Care Med 2002; 165(5): 677-82.

4. Elmasry A, Lindberg E, Berne $C$, et al. Sleep-disordered breathing and glucose metabolism in hypertensive men: a population-based study. J Intern Med 2001; 249 (2):153-61.

5. Sachithanan than V, Loha E, Gose M. Prevalence of diabetes mellitus, hypertension and lipodystrophy in HAART receiving HIV patients in Southern Ethiopia. Internat STD Rese \&Revi2013;1(1):1-11.

6. Yemane T, Belachew T, Asaminew B, Befekadu O. Type II diabetes mellitus in Jimma Town, South West Ethiopia. Eth J Health Sci 2007;17(2).

7. Toyba Endris1 Abebaw Worede2 Daniel Asmelash. Prevalence of Diabetes Mellitus, Prediabetes and Its Associated Factors in Dessie Town, Northeast Ethiopia: A Community-Based Stud. Diabetes, Metabolic Syndrome and Obesity: Targets and Therapy 2019:12 2799-2809; https://www.dovepress.com/terms.

8. Atlas D. International Diabetes Federation. IDF Diabetes Atlas. 7th ed. Brussels, Belgium: International Diabetes Federation; 2015.

9. Nigatu T. Epidemiology, complications and management of diabetes in Ethiopia: a systematic review. J Diabetes, 2012;4:174-80.

10. Mbanya JC, Cruickshank JK, Forrester T, Balkau B, Ngogang JY, Riste L, Forhan A, Anderson NM, Bennett F, and Wilks R. Standardized comparison of glucose intolerance in west African-origin populations of rural and urban Cameroon, Jamaica, and Caribbean migrants to Britain. Diabetes Care, 1999;22(3):434-40.

11. Balde NM, Diallo I, Balde MD, Barry IS, Kaba L, Diallo MM, Kake A, Camara A, Bah D, Barry MM, Sangare-Bah M, and Maugendre D. Diabetes and impaired fasting glucose in rural and urban populations in Futa Jallon (Guinea): prevalence and associated risk factors. Diabetes Metab, 2007;33(2):11420.

12. Abebe SM, Berhane Y, Worku A and Assefa A. Diabetes mellitus in North West Ethiopia: a community based study. BMC Public Health, 2014;14(97):1-8.

13. Tran A, GelayeB, GirmaB, et al. Prevalence of Metabolic Syndrome among Working Adults in Ethiopia. International J. Hypertension, 2011; 193719.

14. Hall V, Thomsen RW, Henriksen O, et al. Diabetes in sub Saharan Africa 1999-2011: epidemiology and public health implications. A systematic review. BMC Public Health 2011;11:564.

15. Motala A, Ramaiya K. Diabetes: the hidden pandemic and its impact on sub- Saharan Africa Diabetes leadership forum; 2010.

16. Roglic G. Who global report on diabetes: a summary? Int J Noncommun Dis 2016; 1.

17. Tesfaye T, Shikur B, Shimels $T$, et al. Prevalence and factors associated with diabetes mellitus and impaired fasting glucose level among members of federal police Commission residing in Addis Ababa, Ethiopia. BMC Endocr Disord 2016; 16:68. 14.

18. Yemane Tet al. Type II diabetes mellitus in Jimma town, Southwest Ethiopia. Ethiopian Journal of Health Sciences 2007;17.

19. Worede A, Alemu S, Gelaw YA, et al. The prevalence of impaired fasting glucose and undiagnosed diabetes mellitus and associated risk factors among adults living in a rural Koladiba town, Northwest Ethiopia. BMC Res Notes 2017;10:251.

20. Bantie GM, Wondaye AA, Arike EB, et al. Prevalence of undiagnosed diabetes mellitus and associated factors among adult residents of Bahir Dar city, northwest Ethiopia: a community- based cross- sectional study. Bantie GM, et al. BMJ Open 2019;9:e030158. doi:10.1136/bmjopen-2019-030158. 
21. Zhou B, Lu Y, Hajifathalian K, et al. Worldwide trends in diabetes since 1980: a pooled analysis of 751 populationbased studies with $4 \llbracket 4$ million participants. The Lancet 2016; 387:1513-30.

22. WHO. Global Report on Diabetes. World Health Organization; 2016.

23. Chawla A, Chawla R, Jaggi S. Microvasular and macrovascular complications in diabetes mellitus: distinct or continuum? Indian J Endocrinol Metab. 2016;20(4):546. doi:10.4103/2230-8210.183480

24. WHO. Global Status Report on Noncommunicable Diseases 2014. World Health Organization; 2014.

25. Cho N, Shaw J, Karuranga S, et al. IDF diabetes atlas: global estimates of diabetes prevalence for 2017 and projections for 2045. Diabetes Res Clin Pract. 2018; 138:271-281. doi:10.1016/j.diabres.2018.02.023.

26. Ogurtsova K, da Rocha Fernandes J, Huang Y, et al. IDF diabetes atlas: global estimates for the prevalence of diabetes for 2015 and 2040. Diabetes Res Clin Pract. 2017; 128:40-50. doi:10.1016/j. diabres.2017.03.024

27. Beagley J, Guariguata L, Weil C, Motala AA. Global estimates of undiagnosed diabetes in adults. Diabetes Res Clin Pract. 2014;103 (2):150-160. doi:10.1016/j.diabres.2013.11.001 